\title{
Hersiening van die Bouwoordeboek: 'n Vorderingsnuusbrief
}

\author{
S. van Niekerk \\ Nasionale Vakterminologiediens
}

In Augustus 1950 het die Ontwerplys Bouterme as eerstelingpublikasie van die Vaktaalburo van die Suid-Afrikaanse Akademie vir Wetenskap en Kuns verskyn. Uit die hersieningswerk aan hierdie prototipe vakwoordeboek het die Bouwoordeboek in Januarie 1960 verskyn - ongeveer 10 jaar later. Nou, 28 jaar later, word daar op versoek van die Akademie weer eens aan die Bouwoordeboek gewerk - hierdie keer deur die Nasionale Vakterminologiediens* van die Departement van Nasionale Opvoeding, in samewerking met 'n redaksiekomitee van vakspesialiste.

Die Redaksiekomitee vir die hersiening en bywerk van hierdie woordeboek het onlangs sy eerste vergadering herdenk wat op 25 September 1987 plaasgevind het - toe die taak nog bloot 'n berg op die horison was! Om sy waardering te toon vir die wye belangstelling vir die projek, wil die komitee met hierdie inligtingstuk graag die een en ander oor sy werk en vordering tot hiertoe meedeel.

Daar is in hierdie tydperk uit sowel akademiese kringe as die private sektor en ook uit die buiteland talle briewe van ondersteuning vir die hersieningstaak ontvang - selfs groepe terme en hele termlyste is tot ons beskikking gestel. Die werk het ook maar pas begin toe van die komiteelede self bykomende bronne voorstel om te raadpleeg. In die proses het die werklading soms gedreig om oorweldigend te raak veral omdat die nuwe groep bykomende terme sover dit die letter A betref, nie van die begin af in die konseplys geïnkorporeer was nie.

Vir die oningewyde, wat verneem dat die terminskrywings vir die letter A maar pas afgehandel is, sou dit kon klink of daar bra min in hierdie jaar bereik is. As daar egter in ag geneem word dat die oorspronklike Bouwoordeboek van $A$ tot $Z$ in totaal 18000 terme sterk was, terwyl die terminskrywings vir die letter $A$ alleen in die voorlopige hersiene vorm nou reeds die 3000 -merk oorskry, word dit duidelik dat 'n groot volume werk in dié tyd verrig is. Afgesien van die toename in die getal terme is heelwat terme ook nog van verklarende aantekeninge voorsien. Meer inligting volg later hieroor.

\footnotetext{
- In 1976 het die Vaktaalburo van die Suid-Afrikaanse Akademie vir Wetenskap en Kuns met die Afdeling Terminologie van die Departement van Nasionale Opvoeding saamgesmelt, waarna dit steeds die "Vaktaalburo" genoem is. In 1984 is dit tot die Nasionale Vakterminologiediens (NVD) herdoop, wat nog steeds onder dieselfde departement ressorteer.
}

Die saamstel van 'n vakwoordeboek is nooit 'n maklike taak nie. Benewens die oorspronklike afbakening van die vakgebied, besinning oor toelaatbare en selfs noodwendige oorvleueling met vakwoordeboeke op ander vakgebiede (in hierdie geval bv. elektrotegniek, aspekte van meganiese ingenieurswese, feitlik alle aspekte van siviele ingenieurswese, akoestiek, houtsoorte en dies meer) het hersiening as taak die bykomende verpligting om ook die bestaande werk onder die loep te neem. Bywerk weer, beteken maar net dat die vordering wat die tegnologie die afgelope 28 jaar beleef het, in die nuwe Bouwoordeboek gestalte moet vind! Verder is nuwe velde ontgin wat in die toekoms 'n groot rol gaan speel, onder meer sonenergie, die sielkunde van argitektuur en veel veel meer.

As objekte met 'n hoë lewensverwagting het geboue verder ' $n$ geskiedenis én ' $n$ hede - hulle is trouens die betroubaarste draers van die kultuur waaruit hulle ontstaan het. Soms ter wille van die skoonheid daarvan, maar dikwels bloot ter wille van hul kultuurhistoriese betekenis, moet ou geboue dus bewaar en les bes gerestoureer word. Iemand wat sou reken dat daar vir die doel van hierdie woordeboek met ontwikkelings in die tegnologie volstaan kan word, het uit die oog verloor dat restourasie nie slegs die opname van sekere terme noodsaak nie, maar minstens vermelding van sekere verouderde prosesse, tegnieke ensovoorts.

As deel van die geesdriftige reaksie op sy oorspronklike bekendstellingsbrief is die komitee onder meer versoek om ter wille van studente in die Boukunde veral die Afrikaanse ekwivalent van terme te verklaar. Daar is selfs voorgestel dat ' $n$ ensiklopediese werk met illustrasies saamgestel word. Tot ons spyt is laasgenoemde nie moontlik nie. Die moeilikste aspek by die saamstel van ' $n$ woordeboek is sekerlik om die begeerte by die samestellers om so wyd en deeglik moontlik te werk, met die beperkinge van die praktyk te versoen - veral waar daar uitstekende bronne van allerlei aard gevind is. Hierdie werkywer en begeestering moet vir die doeleindes van die gedrukte woordeboek steeds getemper word met die noodsaak om ' $n$ hanteerbare - en veral bekostigbare - eindproduk te verkry wat binne die bereik van studente sal wees.

Gelukkig het die tydige totstandkoming van die Nasionale Termbank hierdie probleem - en trouens ook 'n paar ander probleme - vir leksikograwe opgelos, soos uit die onderstaande duidelik sal word. Voordat die rol van die Termbank breedvoeriger ver- 
duidelik word, wil die komitee enkele algemene beleidsaspekte noem.

Heel algemene terme, wat aan die gemiddelde taalgebruiker bekend is en in gewone woordeboeke aangetref word, word nie opgeneem nie, tensy dit om 'n bepaalde rede nodig blyk. By 'n termekwivalent met etlike sinonieme waarvan een in die gebruiksveld duidelike voorkeur geniet, word die sinonieme wel almal as trefwoorde opgeneem, maar soms slegs om na die term te verwys wat na die komitee se bevinding die korrekte of gebruiklike is. Ons hoop om hiermee tog wel 'n diens te lewer aan die vertaler en navorser, wat gewoonlik selfs die blote verwysing na 'n term bo sy algehele weglating verkies!

Ook sal dit nouliks moontlik wees om in so 'n vakwoordeboek die name op te neem van elke soort konstruksie wat teengekom kan word - bv. "woonstelblok" of "administrasiegebou", behalwe waar 'n term bestaan wat die tipe gebou noukeurig beskryf - bv. "toringblok" ens.

Waar moontlik word in verskillende registers gewerk om die belange en behoeftes van elke moontlike gebruiker van die woordeboek te probeer dien - byvoorbeeld ook die argitek of boubestuurder wat hom vir die vloerwerker verstaanbaar wil maak.

Dit is ongelukkig nie moontlik om altyd honderd persent konsekwent met inskrywings te wees nie; 'n term kom soms slegs in die verboë vorm en/of as deel van 'n samestelling voor, of 'n skynbaar onnodige samestelling word opgeneem. Dit gebeur hoofsaaklik in gevalle waar die skryfwyse probleme kan veroorsaak. Op versoek van Engelstalige argitekte en bourekenaars uit Natal en die Kaapprovinsie, wat graag die terminologie van spesifikasies, tenderdokumente en so meer in die woordeboek opgeneem wil hê, het die komitee nóg verder gegaan en waar moontlik die terminologie van die Nasionale Bouregulasies, wat in die Staatskoerant verskyn het, opgeneem.

Sover dit terme uit oorvleuelende vakgebiede raak, probeer die komitee slegs die terme selekteer wat regstreeks by die boubedryf betrokke is, en dan nie met bykomende inligting nie. Elke vakgebied word van ' $n$ vakkode voorsien wat in die konsepvorm die laaste inligting van elke terminskrywing is. In die gespesialiseerde vakgebiede word beoog om terme wat op diè wyse gemerk is, in afsonderlike lêers oor te skryf. Hiervan word rekenaardrukstukke vir finale seleksie, keuring en desnoods aanvulling aan spesialiste in daardie betrokke vakgebied gestuur. Die verwagting is om met soveel deskundige hulp die voorkoms van foutiewe data of foutinskrywings werklik tot die minimum te beperk.

Die komitee werk nie slegs per letternaam nie, maar veral tematies, sodat die huidige lys talle terme bevat wat uit navorsing oor 'n term met " $A$ " as beginletter ontstaan het, maar onder ander alfabetletters tuishoort. So lei die term "air-to-air heat resistance" bv. na "thermal transmittance", wat die opname van "thermal capacity", "thermal conductance", "thermal resistance (of walls)" en "thermal movement" noodsaak, en in "moisture movement" eindig. Dit alles onder die vaandel van die letter " $A$ " - en in 'n poging om die warmtedeurlating van mure te bepaal. Die alfabetisering vind darem later plaas! So 'n werkwyse is oënskynlik remmend, maar behoort in 'n groot mate te verhoed dat noodsaaklike terme weggelaat word.

Met die totstandkoming van die Termbank het daar wonderlike nuwe moontlikhede vir die huisvesting van terminologie met 'n verskeidenheid inligting ontstaan. Aangesien die meeste terme voor opname deeglik nagevors moet word, het die komitee besluit om die resultaat van hierdie navorsing, wat vanweë die beperkte plaasruimte nie in die woordeboek kan verskyn nie, nogtans in die Termbank te berg. Rekenaardrukstukke wat die navorsingswerk van die komitee bevat, sal dan op aanvraag aan persone en instansies beskikbaar gestel kan word. 'n Voorbeeld van hiedie inligting is: "transept: transep\$\$ Part of a cruciform at right angles to the nave and chancel (the North and South arms are always called 'North transept' and 'South transept'). Some cathedrals have an additional transept east of the crossing"'. Die Afrikaans hiervan word weer ingevoeg waar Afrikaans die uitgangstaal is.

Dit beteken nie dat 'n verklarende woordeboek in hierdie stadium beoog word nie - die volume van die inligting sal dit waarskynlik onmoontlik maak maar die komitee wil graag die beste diens moontlik met dié vakwoordeboek lewer. Die inligting word versamel en so noukeurig moontlik beoordeel, maar relatief min van die data kan in die Bouwoordeboek opgeneem word. Dit sal egter wel volledig geberg en uit die Nasionale Termbank opgevra kan word.

Terme wat tog in die woordeboek verklaar word, is onder meer dié wat vir die boukunde belangrike tegnologiese inligting verteenwoordig. So byvoorbeeld word die term "alkali-aggregaatreaksie: alkaliaggregate reaction" ingeskryf met die bygaande verklaring: " 'n Chemiese reaksie in dagha of beton tussen alkalieë in die sement en die bestanddele van sekere aggregate, wat skadelike uitsetting van die sement of beton kan veroorsaak"; en "allowable load (permissible load): toelaatbare las\$ The maximum load which may be applied with safety to a critical structural member", ensovoorts.

Daarenteen kry "'alidade (surveying instrument)", "aesthetics (of buildings)" en "airing cupboard (linen)" elk net 'n verband om die betekenis te suggereer. Voorlopig word alle navorsing tweetalig gedoen en die bronne vir latere verwysing volledig opgeteken. Die komitee sal hom uiteindelik vir die opname van noodsaaklike inligting deur veral doserende personeel en vakspesialiste laat lei.

Waar die data oor bepaalde subvakgebiede later uitgebreid genoeg is, kan dit weer beteken dat die komitee se sorgvuldige werk na 'n aantal jare nie alleen die hersiene, bygewerkte Bouwoordeboek nie, maar moontlik enkele kleiner, selfstandige woordeboeke oor vakke soos Boureg, Lugversorging, Akoestiek, Teaterbou, Verligting, Restourasie, Passiewe sonenergie en so meer tot gevolg kan hê. 
Daar word uit 'n omvattende bronnelys - in die orde van ses-en-vyftig werke - geëkserpeer. Terme van Engelse oorsprong geniet voorkeur. Waar dit by terme van Amerikaanse, Kanadese of Australiese oorsprong kom, laat die komitee hom lei deur die land wat op ' $n$ bepaalde tegnologiese gebied die pionier is, bv. die Verenigde State van Amerika op die gebied van energiebesparing.

Sonder die Termbank sou dit waarskynlik nie moontlik gewees het om al die relevante inligting te berg of beskikbaar te stel nie, dus wil dit voorkom of die lang wagtyd tussen die eerste verskyning van die Bouwoordeboek en hierdie omvattende hersieningswerk, waarvan die eerste skof maar pas voltooi is, tog sinvol was. Die Redaksiekomitee wil hiermee die hoop uitspreek dat belanghebbendes by hierdie vak met geduld op die hersiene en bygewerkte uitgawe van die Bouwoordeboek sal wag. Persone wat in die verlede vergeefs na sekere bouterme gesoek het, word hiermee vriendelik genooi om die betrokke terme, asook terme wat hulle graag in die nuwe woordeboek opgeneem wil hê, aan die Nasionale Vakterminologiediens te stuur** - al is dit maar een enkele term.

Met wye samewerking en die waardevolle bydraes van vakspesialiste hoop die komitee om uiteindelik 'n woordeboek saam te stel wat in hoë mate aan die vereistes van sy verskillende gebruikers sal voldoen.

** Bydraes kan gestuur word aan Die Hoof, Bouwoordeboek, Nasionale Vakterminologiediens, Privaatsak X122, Pretoria 0001. 